\title{
Wavelet Multiresolution Analysis of the Liquidity Effect and Monetary Neutrality
}

\author{
Olivier Habimana ${ }^{1,2}(\mathbb{D}$
}

Accepted: 27 July 2017 / Published online: 18 August 2017

(C) The Author(s) 2017. This article is an open access publication

\begin{abstract}
This paper employs the maximum overlap discrete wavelet transform to obtain timescale decompositions of monetary aggregates, short-term interest rates and output to investigate two propositions in monetary economics: the liquidity effect and the long-run neutrality of money. Evidence from correlation and Granger causality over five timescales suggests that the liquidity effect is statistically significant in both the US and Sweden's economies, with a shorter time horizon in the US than in Sweden. There is no evidence of monetary neutrality in both economies; at finest timescales, output Granger causes money in Sweden, whereas it is the other way around in the US. At long time horizons, there is a feedback between money and output in both economies. Key to our findings is that monetary disturbances have significant real effects and these effects last longer than it is assumed in real business cycle models.
\end{abstract}

Keywords Granger causality $\cdot$ Liquidity effect $\cdot$ Monetary neutrality $\cdot$ Multiresolution analysis (MRA) · Wavelets

JEL Classification E43 · E52 · C63

\section{Introduction}

Unlike the traditional view of macroeconomic fluctuations, in real business cycle (RBC) models, as well as in other models that assume completely flexible prices,

$凶$ Olivier Habimana

olivier.habimana@ju.se

1 Department of Economics, Finance and Statistics, Jönköping International Business School, Jönköping University, Box 1026, 55111 Jönköping, Sweden

2 Department of Applied Statistics, College of Business and Economics, University of Rwanda, Kigali, Rwanda 
monetary changes have no real effects, even in the short run. As Romer (2012) points out, examining the real effects of monetary disturbances is a critical test of pure RBC models.

The debate on the role of money in the economy is as old as economics. The theory of liquidity preference, as pioneered by Keynes in the General Theory of Employment, Interest and Money, postulates that interest rate is the price that equilibrates the desire to hold wealth in the form of cash with the available quantity of cash. Thus, in the short run, an increase in money supply induces a decrease in nominal interest rate. This short-run negative relationship is called the liquidity effect.

Another central tenet of macroeconomics is the long-run neutrality of money. The proposition that the change in money stock changes nominal prices (and wages) and does not affect real variables such as output, employment, real interest rates and real wages. In his Nobel Prize lecture, Lucas (1996) discusses money neutrality in particular and the quantity theory of money (QTM) in general. The central prediction of the QTM is that in the long run money is neutral. However, Lucas highlights the ambiguous nature of the terminology "long run". Since economic agents make decisions at different time horizons, this terminology is relative. In the mainstream economics, the time horizon has been simplified to short and long run. This restriction to only two time horizons has been a matter of convenience and pedagogical advantage, for, until recently, there were no tools to decompose economic time series into detailed timescales (Ramsey and Lampart 1998).

There is mixed empirical evidence on these two rather important propositions in monetary economics. This paper seeks to shed more light on the relationship between money and interest rate, and money and output using wavelets to decompose series into detailed timescales. Wavelets can be defined as lens that allow zooming the series in and out to explore relationships that would otherwise be unobservable (Ramsey 2002). They are powerful tools to analyze non-stationary (non-periodic) time series, a rather typical feature of macroeconomic time series.

The rest of the paper is organized as follows. Section 2 discusses previous studies. Section 3 describes the econometric methods. Section 4 describes the data and presents and discusses empirical results. Section 5 concludes.

\section{Literature Review}

\subsection{Liquidity Effect}

Mishkin (1982) pioneered the search for empirical evidence of the liquidity effect in the US economy. However, using rational expectations models, Mishkin could not find empirical support that the increase in the money stock is associated with a decline in short-term interest rates. This anomaly has been since called the liquidity puzzle (see Melvin 1983; Christiano 1991; Leeper and Gordon 1992; Bernanke et al. 2005, to mention but a few).

One attempt to explain the liquidity puzzle has been to argue that broad monetary aggregates are not good indicators of monetary policy because changes in monetary aggregates can result from factors other than changes in policy (Serletis and Chwee 
1997). Several attempts to solve the liquidity puzzle include, inter alia, using nonborrowed reserves as an indicator for monetary policy (Eichenbaum 1992), extending the federal-funds VAR by including a proxy for the Fed's information about inflation (Sims 1992), considering non-borrowed monetary base shocks (Serletis and Chwee 1997), and using the federal-funds rate as an indicator of monetary policy actions (Bernanke and Blinder 1992). In this line of research, Kelly et al. (2011) argue that the liquidity puzzle is due to measurement errors in narrowly defined monetary aggregates. Kelly et al. then empirically find that the broadest monetary aggregate exhibits stronger liquidity effects.

Studies discussed above have been conducted in the time-domain. The timefrequency analysis has been recently applied by Michis (2015) to investigate the liquidity effect in the UK economy. He employs standardized regressions, a framework proposed by Cochrane (1989). His findings suggest that in short-term cycles, interest rates are influenced primarily by changes in the money supply. In mediumand long-term cycles, the liquidity effect becomes less important. As Michis further argues, this evidence would not be obtained if only the observed sampling rate of the series was studied because sampling provides a mixture of the different frequencies and masks differences between short-term and long-term relationships. Our analysis is similar to Michis's except that we don't assume that interest rate is exogenous to money supply, instead we examine causality in both directions.

\subsection{Monetary Neutrality}

Andersen and Jordan (1968) pioneered this field of research and regressed output on money using the famous St. Louis equation. The idea behind the St. Louis equation is that the effect, if any, of money on output may occur with a lag. The authors also suggest including a constant and a time trend in the equation as follows:

$$
\Delta \ln y_{t}=\alpha+\beta_{0} \Delta \ln m_{t}+\sum_{i=1}^{4} \beta_{i} \Delta \ln m_{t-i}+\delta t+\varepsilon_{t}
$$

Romer (2012) argues that although this type of regression can reveal the association between money (m) and output (y), it does not provide powerful evidence in support of monetary over real theories of fluctuations. That is, there is no convincing reason to assume that money supply is exogenous to output; the causation may run from output to money as well. Romer discusses several other limitations associated with the St. Louis equation.

To overcome the shortcomings of the St. Louis equation, Sims (1986) and Gali (1992) in the IS-LM model framework, Bernanke and Mihov (1998), and Bagliano and Favero (1998), among others, have employed VAR methodology to examine the role of monetary policy. However, as Romer (2012), Rudebusch (1998) and Bernanke et al. (2005) point out, VAR methodology has been also haunted by the same difficulties as the St. Louis equation. First, VARs do not reflect the information that central banks and the private sector have, which contaminates the measurement of policy innovations. Second, the choice of the variables to represent real activity has been arbitrary. Third, 
the impulse responses can be observed only for a small subset of the variables, those that are included, excluding therefore other variables that may be of importance to policy-makers.

Christiano and Ljungqvist (1988), in a seven-lag VAR, perform a bivariate Granger causality test on M1 and industrial production, and find statistically significant causality when series are measured in levels, but this significance vanishes when series are measured in first difference. They argue that differencing the series entails a specification error. Ever since many studies have applied VAR methodology and have produced mixed results (see, for example, Psaradakis et al. 2005; Canova and Menz 2011).

The causality between money and output is not only sensitive to the methods used but also to sample length. Berger and Österholm (2009) argue that there are clear indications of a systematic reduction in the role of money after the Great moderation of the mid-1980s, and that money ceases to Granger-cause output around Paul Volcker's chairmanship at the Federal Reserve (1979-1987). The same argument was advanced by Friedman and Kuttner (1993). On the other hand, Swanson (1998) claims that the causality between money and output is stable across time. Thoma (1994) investigates this stability using recursive methods and rolling through the sample and finds that the Granger causality between money and output is time-varying. Thoma suspects that instability reflects the existence of an asymmetric ${ }^{1}$ relationship between the two variables.

Other studies have employed cointegration to test for long-run monetary neutrality (Hafer and Jansen 1991; Westerlund and Costantini 2009; Koustas 1998). However, Fisher and Seater (1993) and Lee (2012) argue that testing for cointegration is not equivalent to testing for long-run neutrality. Indeed long-run neutrality is testable irrespective of the presence of cointegration between money and output.

Recently, Ventosa-Santaulària and Noriega (2015) employ long-horizon regression on annual series of Australia, Argentina, Brazil, Canada, Italy, Mexico, Sweden and the UK. Their findings suggest that the long-run monetary neutrality ${ }^{2}$ seems to hold for all the mentioned countries.

The empirical literature on monetary neutrality suffers from three main flaws. Some studies assume that money supply is exogenous; others try to identify the exogenous component of monetary policy and its effects on the economy (see, for instance, Bernanke and Mihov 1998). The second flaw refers to the traditional division of time into only two scales: the short run and the long run. We argue that the short run, as well as the long run, depends on each economy. More specifically, the time horizon of policy intervention differs in countries, and so do the short run and the long run. The other limitation, which may sound subtle, is the frequency of the time series. Studies that analyze annual data of output and money (see, for instance, Noriega et al. 2008; Ventosa-Santaulària and Noriega 2015) ignore the fact that monetary policymakers may intervene at horizons shorter than a year. As Ramsey and Lampart (1998) point out, the focus of policy is different at each horizon, and so is the degree of

\footnotetext{
1 The asymmetric effect of monetary policy on output has been investigated in Markov-switching models (see, for example, Lo and Piger 2005; Psaradakis et al. 2005).

2 They also find spurious non-neutrality when money and output follow the same (deterministic or stochastic) trend, and when they follow combinations of broken trends and unit roots.
} 
time aggregation. ${ }^{3}$ The approach in the present paper overcomes some of these flaws. We decompose monthly series into five timescales and investigate correlation and causality at each scale.

\section{Granger Causality and Wavelet Analysis}

\subsection{Granger Causality}

Following Granger (1969) and Sims (1972), causality between money and interest rate (the same procedure is followed for money and output) is tested using the following bivariate vector autoregressive (VAR) representation:

$$
\begin{gathered}
m_{t}=\alpha_{0}+\sum_{j=1}^{k} \alpha_{m, j} m_{t-j}+\sum_{j=1}^{k} \alpha_{i, j} i_{t-j}+\varepsilon_{m, t} \\
i_{t}=\beta_{0}+\sum_{j=1}^{k} \beta_{m, j} m_{t-j}+\sum_{i=1}^{k} \beta_{i, j} i_{t-j}+\varepsilon_{i, t}
\end{gathered}
$$

where $i_{t}$ is interest rate, $m_{t}$ is nominal money, and $\varepsilon_{m, t}$ and $\varepsilon_{i, t}$ are white noise processes, independent of each other. If money Granger causes interest rate, the change in money should come before the change in interest rate. The lagged value of money should help predict the current values of interest rate, and the past values of interest rate should not have any significant power in explaining the current variation in money (Gençay et al. 2002, p. 150).

When $i_{t}$ and $m_{t}$ are both I (1), their linear combination may be stationary, and Engle and Granger (1987) suggest specifying an Error correction model (ECM) as follows:

$$
\begin{aligned}
\Delta m_{t} & =\alpha_{0}+\gamma_{1}\left(m_{t-1}-i_{t-1}\right)+\sum_{j=1}^{k}\left(\alpha_{m, j} \Delta m_{t-j}+\alpha_{i, j} \Delta i_{t-j}\right)+\varepsilon_{m, t} \\
\Delta i_{t} & =\beta_{0}+\gamma_{2}\left(m_{t-1}-i_{t-1}\right)+\sum_{j=1}^{k}\left(\beta_{m, j} \Delta m_{t-j}+\beta_{i, j} \Delta i_{t-j}\right)+\varepsilon_{i, t}
\end{aligned}
$$

where $\gamma_{1}$ and $\gamma_{2}$ represent the speed of adjustment. The following hypotheses are tested:

(a) $\alpha_{i, 1}=\alpha_{i, 2}=\cdots=\alpha_{i, k}=0$ and $\gamma_{1}=0$

(b) $\beta_{m, 1}=\beta_{m, 2}=\cdots=\beta_{m, k}=0$ and $\gamma_{2}=0$

If (a) is rejected, there is evidence that interest rate Granger causes money. When (b) is rejected, one concludes that money Granger causes interest rate. If the two

3 Ramsey and Lampart (1998) employ wavelets to decompose nominal personal income (NPI) and monetary aggregates to investigate the income velocity of money in the US economy. Their findings suggest significant variations across scales in the relationship between the two variables. 
hypotheses are rejected simultaneously, there is a feedback mechanism. The results are inconclusive if none of the two hypotheses is rejected.

Following Toda and Yamamoto (1995) and Dolado and Lütkepohl (1996), it is possible to estimate a VAR in levels ${ }^{4}$ even when the processes are integrated. The standard asymptotic theory for hypothesis testing in the VAR still holds provided that the order of integration of the process $\left(\mathrm{d}_{\max }\right)$ is not greater than the true lag length of the model (k). Toda and Yamamoto suggest to first determine the lag length $\mathrm{k}$, then estimate a $\left(k+d_{\max }\right)$ th order VAR. Accordingly, Eqs. (2) and (3) are estimated with one extra $\operatorname{lag}^{5}$ and the coefficients matrices of the last $\mathrm{d}_{\max }$ lagged vectors are ignored. The causality test is based on Granger (1969).

\subsection{Wavelet Multiresolution Analysis}

Wavelet multiresolution analysis (MRA) consists of decomposing the time series into different scales of variations using the wavelet transform. A time series $x(t)$ is decomposed into detail and smooth coefficients using the father $(\phi)$ and the mother $(\psi)$ wavelets, respectively.

The father wavelet is defined as (see Ramsey and Lampart 1998)

$$
\phi_{J, k}=2^{-J / 2} \phi\left(\frac{t-2^{J} k}{2^{J}}\right), \quad j=1,2, \ldots, J ; \quad k=0,1, \ldots 2^{j}-1
$$

The mother wavelet is defined as

$$
\psi_{j, k}=2^{-j / 2} \psi\left(\frac{t-2^{j} k}{2^{j}}\right), \quad j=1,2, \ldots, J ; \quad k=0,1, \ldots 2^{j}-1
$$

where the integer $j$ is the dilation or scaling parameter that determines the width (or size) of the wavelet; the integer $k$ is the translation parameter that determines the location of the wavelet; $\phi($.$) and \psi($.$) are real valued functions defined over real axis$ $(-\infty, \infty)$ and satisfying the following basic property:

$$
\int_{-\infty}^{\infty} \phi(t) d t=1 \text { and } \int_{-\infty}^{\infty} \psi(t) d t=0 .
$$

The mother wavelet gives the detail coefficients (high-frequency components) at scales 1 to $\mathrm{J}$ as follows:

$$
d_{j, k}=\int_{-\infty}^{\infty} x(t) \psi_{j, k}(t) d t, \quad j=1,2, \ldots, J
$$

The smooth coefficient (low-frequency component) is computed at the highest multiresolution level $\mathrm{J}$ using the father wavelet:

\footnotetext{
4 The conventional asymptotic theory is not applicable to hypothesis testing in VAR when the series are integrated or cointegrated (Park and Phillips 1989; Sims et al. 1990). The remedy has been to estimate VAR in first differences when the series are I (1), or to specify the ECM when the series are cointegrated.

5 Because the series are integrated of order one (see unit root test results in "Appendix"), one extra lag assures that residuals are stationary in each equation.
} 


$$
s_{J, k}=\int_{-\infty}^{\infty} x(t) \phi_{J, k}(t) d t, \quad j=1,2, \ldots, J
$$

It is then possible to represent $x(t)$ as the sum of smooth $s_{J}$ and detail coefficients $d_{j}$ as follows (see Ramsey 2002):

$$
\begin{aligned}
x(t)= & \sum_{k} s_{J, k} \phi_{J, k}(t)+\sum_{k} d_{J, k} \psi_{J, k}(t)+\sum_{k} d_{J-1, k} \psi_{J-1, k}(t)+\cdots \\
& +\sum_{k} d_{1, k} \psi_{1, k}(t)
\end{aligned}
$$

which can be expressed in a more compact and intuitive way as

$$
x(t)=S_{J}+D_{J}+D_{J-1}+\cdots+D_{1}
$$

$\begin{aligned} S_{J} & =\sum_{k} S_{J, k} \phi_{J, k}(t) \\ \text { where } & D_{j}=\sum_{k} d_{j, k} \psi_{j, k}(t), \mathrm{j}=1,2, \ldots, \mathrm{J} .\end{aligned}$

Small values of $\mathrm{j}$ correspond to low-scale (high-frequency) components of $x(t)$, whereas large values of $\mathrm{j}$ correspond to high-scale (low-frequency) components of $x(t) . D_{j}$ coefficients capture cyclical movements of $2^{\mathrm{j}}$ to $2^{\mathrm{j}+1}$ periods, thus D1 captures cyclical movements of 2-4 periods, D2 captures cyclical movements of $4-8$, and so on.

To perform the MRA, it is important to choose a suitable wavelet transform. Two types of discrete wavelet transforms have so far dominated the literature: the discrete wavelet transform (DWT) and the maximal overlap discrete wavelet transform (MODWT). We opt for the MODWT, which is improvement over the DWT. The MODWT can handle any sample size, unlike dyadic length requirement (sample size divisible by $2^{\mathrm{J}}$ ) of the DWT. Moreover, whereas the DWT uses weighted differences and averages over contiguous pairs of observations, the MODWT uses a moving difference and average operator and keep the exact amount of observations at each scale (Sjölander et al. 2015). Percival and Mofjeld (1997) highlight four main properties that distinguish the two transforms (see Gençay et al. 2002, p. 135). The computation of the MODWT coefficients is described in "Appendix".

After choosing the wavelet transform, one needs to select an appropriate wavelet filter. The selection of a particular wavelet should take into account the length of the data, complexity of the spectral density function, and the underlying shape of features in the data in order to achieve a balance between frequency localization and time localization (Gençay et al. 2010). When the spectral density function of the series is quite dynamic, longer ${ }^{6}$ wavelets are appropriate in order to separate the activity

\footnotetext{
6 Longer filters are not devoid of problems. They produce more outliers at the endpoints (boundaries) of the detail series than shorter filters, especially at the lower scales. To reduce the effect of the boundary coefficients, some studies suggest that the detail series should be truncated from the left and/or right prior to performing further analysis (see Andersson 2008; Scott Hacker et al. 2012). However, the effects of boundary coefficients depends of the length and the frequency of the time series; "with the luxury of
} 
between scales. To balance smoothness, length and symmetry, the Daubechies least asymmetric wavelet of length eight, LA(8) is recommended. The LA (8) wavelet produces uncorrelated and relatively smooth coefficients while having a filter width short enough such that the impact of boundary conditions is tolerable (Cornish et al. 2006; Gençay et al. 2002).

In addition to the LA(8) wavelet, for robustness checks, Haar wavelet [proposed by Haar (1910)] and the Daubechies wavelet of length four, D(4) [proposed by Daubechies (1988)] are also used to decompose the series. While the LA(8) wavelet is based on eight nonzero coefficients, $\mathrm{D}(4)$ wavelet is based on four nonzero coefficients, and Haar is based on two nonzero coefficients. These wavelets have compact support in the interval $[0, \mathrm{~L}-1]$, where $\mathrm{L}$ denotes the wavelet length. That is, the LA(8) wavelet has compact support in the interval $[0,7]$, the $\mathrm{D}(4)$ wavelet has compact support in the interval $[0,3]$, and the Haar wavelet has compact support in interval $[0,1]$.

The Haar scaling function (father wavelet) is the simplest. It is defined as (see Daubechies 1992, p. 115)

$$
\phi^{\text {Haar }}(x)=\left\{\begin{array}{l}
1, \text { if } 0 \leq x \leq 1 \\
0, \text { if otherwise }
\end{array}\right\}
$$

The Haar mother wavelet is defined as

$$
\psi^{\text {Haar }}(x)=\left\{\begin{array}{ll}
1, & \text { if } 0 \leq x \leq \frac{1}{2} \\
-1, & \text { if } \frac{1}{2} \leq x \leq 1 \\
0, & \text { if otherwise }
\end{array}\right\}
$$

The Daubechies wavelet of length four, D(4) is defined as follows:

The father wavelet (scaling function) is given by

$$
\phi^{D(4)}(x)=\sum_{l} g_{l} \phi(2 x-l) \quad l=0,1, \ldots, 3
$$

where $\mathrm{L}$ is a positive integer that indicates the length of the wavelet filter; $g_{0}, \ldots, g_{3}$ are the scaling (low pass) filter coefficients, reported in Table 1.

The corresponding $\mathrm{D}(4)$ mother wavelet is

$$
\psi^{D(4)}(x)=\sum_{l} h_{l} \phi(2 x-l) \quad l=0,1, \ldots, 3
$$

where, $h_{0}, \ldots, h_{3}$ are wavelet (high pass) filter coefficients that are related to the scaling filter coefficients via the following quadrature mirror and inverse quadratic mirror relationships, respectively (see Percival and Walden 2006, p. 75):

$$
g_{l} \equiv(-1)^{l+1} h_{L-1-l} \text { and } h_{l}=(-1)^{l} g_{L-1-l} \quad l=0,1, \ldots, 3
$$

Footnote 6 continued

high-frequency data, the effects of boundary wavelet coefficients are minimized and we are allowed to select from longer filters if necessary" (Gençay et al. 2010, p. 901). 
Table 1 Haar, D(4) and LA(8) scaling filter coefficients $\left(g_{l}\right)$

\begin{tabular}{llrr}
\hline$l$ & Haar & $\mathrm{D}(4)$ & \multicolumn{1}{c}{ LA(8) } \\
\hline 0 & 0.7071067811865475 & 0.482962913144534 & -0.0757657147893407 \\
1 & 0.7071067811865475 & 0.836516303737807 & -0.0296355276459541 \\
2 & & 0.224143868042013 & 0.4976186676324570 \\
3 & -0.129409522551260 & 0.8037387518052160 \\
4 & & 0.2978577956055420 \\
5 & & -0.0992195435769354 \\
6 & & -0.0126039672622612 \\
7 & & 0.0322231006040713
\end{tabular}

These scaling filter coefficients $\left(g_{l}\right)^{\mathrm{a}}$ are reported in Table 6.3 of Daubechies $(1992$, p. 193) and in Table 109 of Percival and Walden (2006, p. 109). Both books use different normalization; the coefficients reported here are based on the normalization in Percival and Walden (2006), namely $\sum_{l} g_{l}=\sqrt{2}$. See Percival and Walden, page 117 for further details.

a These coefficients can be downloaded on http://staff.washington.edu/dbp/wmtsa.html

The mother and father wavelets for the LA(8) wavelet are also derived in a similar way. The father wavelet (scaling function) is defined as

$$
\phi^{L A(8)}(x)=\sum_{l} g_{l} \phi(2 x-l) \quad l=0,1, \ldots, 7
$$

where $g_{0}, \ldots, g_{7}$ are scaling filter coefficients, reported in Table 1.

The corresponding mother wavelet is

$$
\psi^{L A(8)}(x)=\sum_{l} h_{l} \phi(2 x-l) \quad l=0,1, \ldots, 7
$$

where $h_{0}, h_{1}, \ldots, h_{7}$ are the wavelet filter coefficients.

The MRA is carried out using the MRA function that executes the pyramid algorithm originally proposed by Mallat (1989). The MRA function is a component of R package waveslim. All computations are carried out in $\mathrm{R}$ version 3.1.3.

\section{Data and Empirical Results}

\subsection{Data Description}

Seasonally adjusted monthly data for short-term interest rates (yields on 3-month T-bill), monetary aggregate $(\mathrm{M} 1)^{7}$, and the industrial production index (a proxy for

\footnotetext{
7 Monetary aggregates are defined according to OECD statistics. M1 is currency, i.e., banknotes and coins, plus overnight deposits. M2 is the sum of M1, deposits with an agreed maturity of up to 2 years and deposits redeemable at notice of up to 3 months. And broad money-M3 is the sum of M2, repurchase agreements, money market fund shares/units and debt securities up to 2 years.
} 
output because monthly GDP is not available) are obtained from the Federal Reserve Economic Data (FRED) for the period January 1990 until December 2014 for the US, and January 1998 until December 2013 for Sweden. Series are in levels except M1 that is expressed in natural logarithm. Unit root test results (see Table 12 in "Appendix") indicate that all the series are I (1), i.e., they are nonstationary in levels but their first difference is stationary. Nonstationarity implies that it would not be appropriate to decompose the series with traditional spectral tools such as the Fourier transform (FT) that can only capture features that are periodic and globally stationary. The timescale decomposition in this study is thus based on the MODWT.

\subsection{Timescale Decomposition}

Series are decomposed using the LA(8), Haar and $\mathrm{D}(4)$ wavelets. To capture a long time-horizon, $\mathrm{J}$ is set equal to 5. Figures 1 and 2 plot M1 and its MODWT coefficients for Sweden and the US. The wavelet details D1 to D5 are associated with cyclical movements of 2-4, 4-8, 8-16, 16-32, and 32-64 months, respectively. S5 represents the long-term trend. For both countries, M1 exhibit different variability at different time horizons. S5 shows that M1 peaks around mid-2011 for Sweden, and end-2012 for the US.

Figure 3 plots correlations between money and short-term interest rates at different timescales. All the correlation coefficients are negative and significant (see Table 2). In both economies, the magnitude of the correlation is higher at the finest scale of 2-4 months and decreases afterward. The correlations are higher for the US at all scales. Whereas the correlation reaches around 0.7 at the fifth scale (corresponding to a 5-year movement) for Sweden, it stays above 0.9 for the US. These results suggest that the liquidity effect is stronger and more persistent in the US than in Sweden.

Unlike some studies that suggest that the liquidity effect is not stable, and that the correlation often becomes positive (see, for instance, Leeper and Gordon 1992), our results suggest that the correlation between money and short-term interest rate is negative at all timescales.

Figure 4 plots correlations between money and output at different timescales. All the coefficients are positive (see Table 2) and above 0.87 for the US at all scales, whereas they are between 0.17 and 0.4 for Sweden. The correlation is only significant up to the third scale (16-month cycle movements) for Sweden, and persists up to 5 year cycle movements (fifth timescale) for the US.

\subsection{Main Results and Discussion}

The results of Granger causality test reported in Table 3 and summarized in Table 5 suggest that the liquidity effect is an empirical regularity in both economies. In accordance with the findings from multiscale correlations, where at the finest scale (2-4 months) money is negatively and significantly correlated with short-term interest rate ( -0.9174 and -0.9489 for Sweden and the US, respectively), at the same finest scale money Granger causes short-term interest rates in both economies. This effect persists 

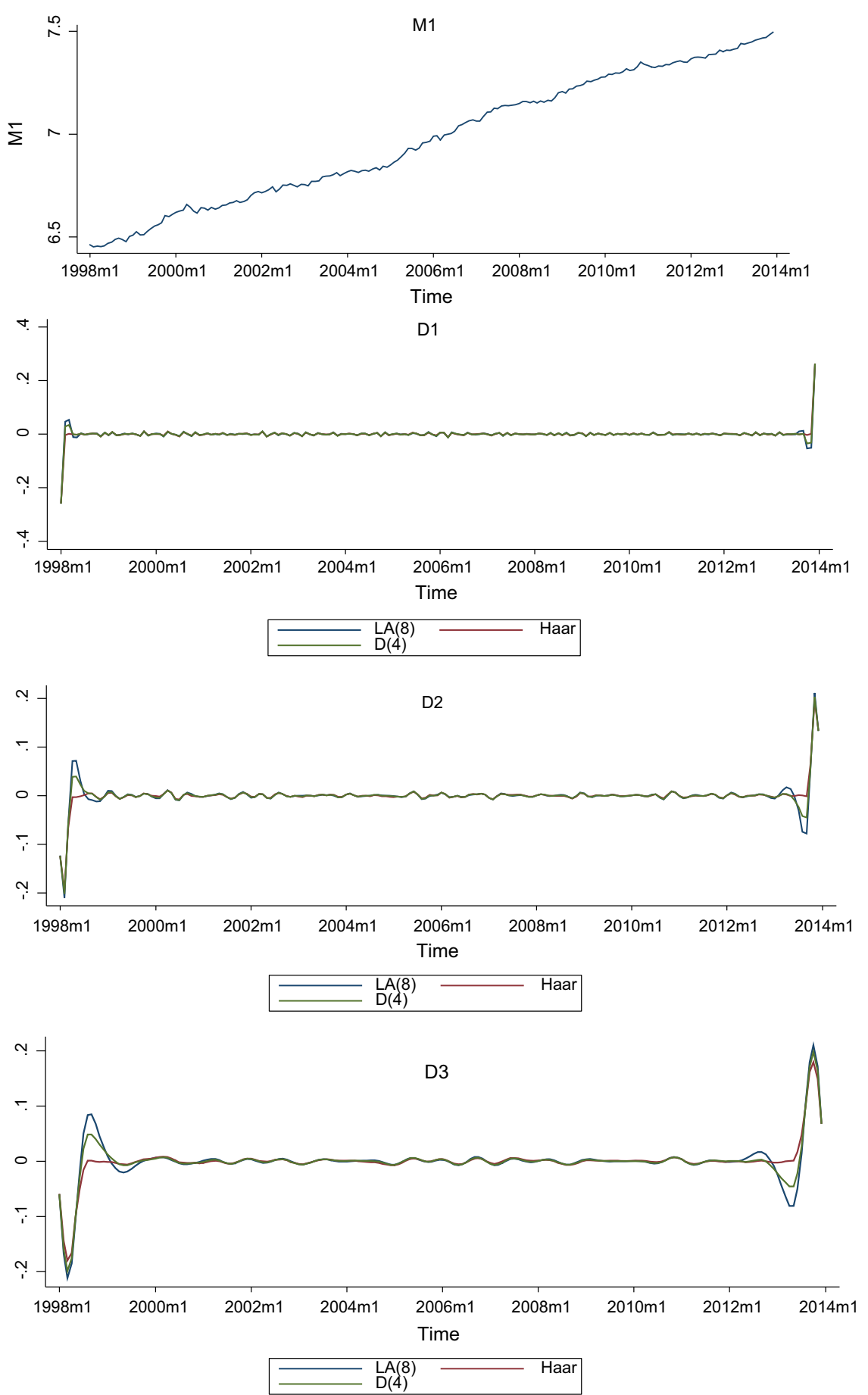

Fig. 1 M1 and its MODWT coefficients, Sweden 

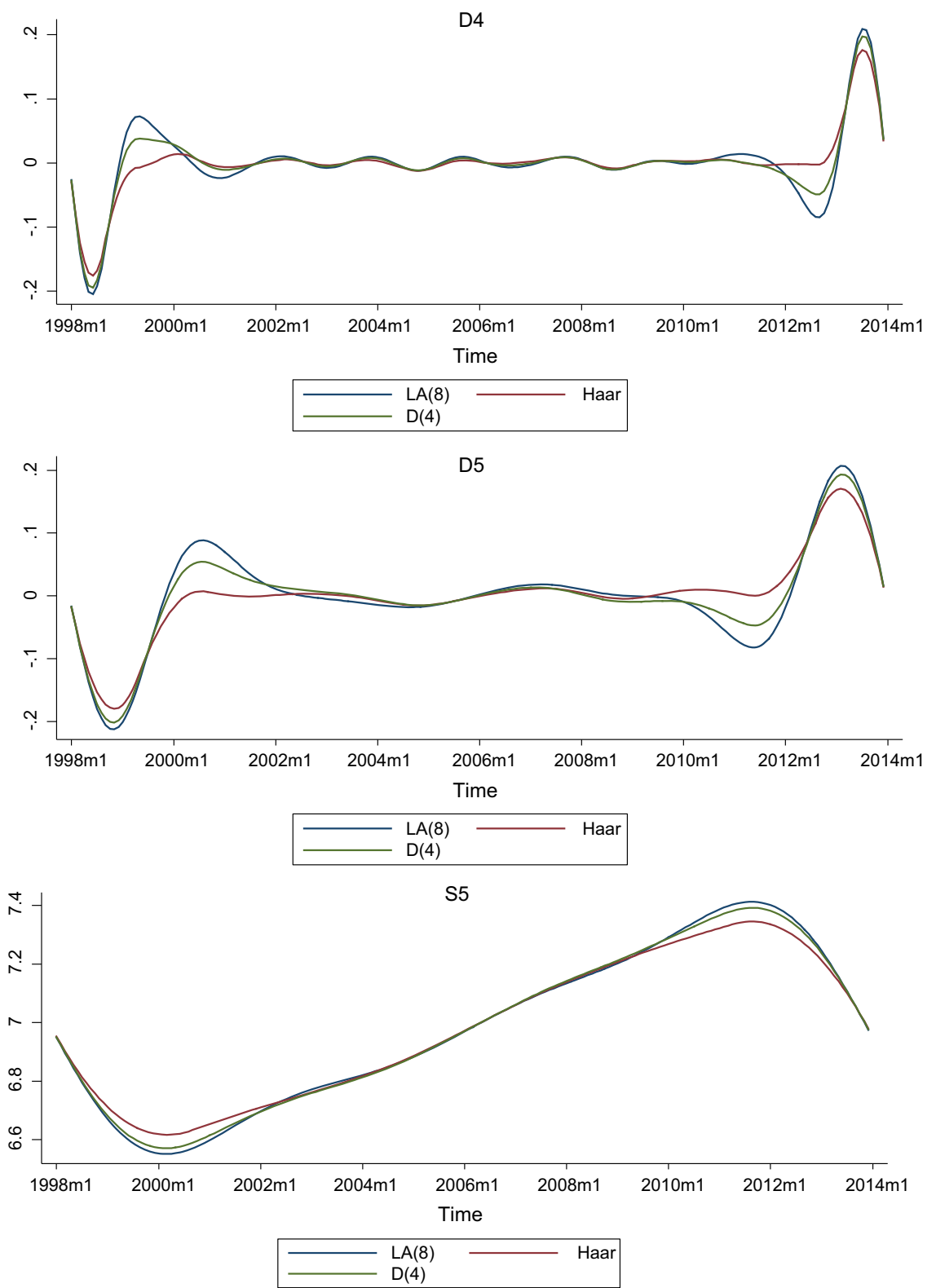

Fig. 1 continued

at the second wavelet scale (4-8 months) for Sweden. At the intermediate scales (4-8 months for the US and 8-16 months for Sweden) the test is inconclusive.

At higher scales (from the fourth scale for Sweden, and the third scale for the US) there is a feedback between money and short-term interest rate in both economies. This feedback is a sign of the monetary policy horizon; at long time horizons, central 

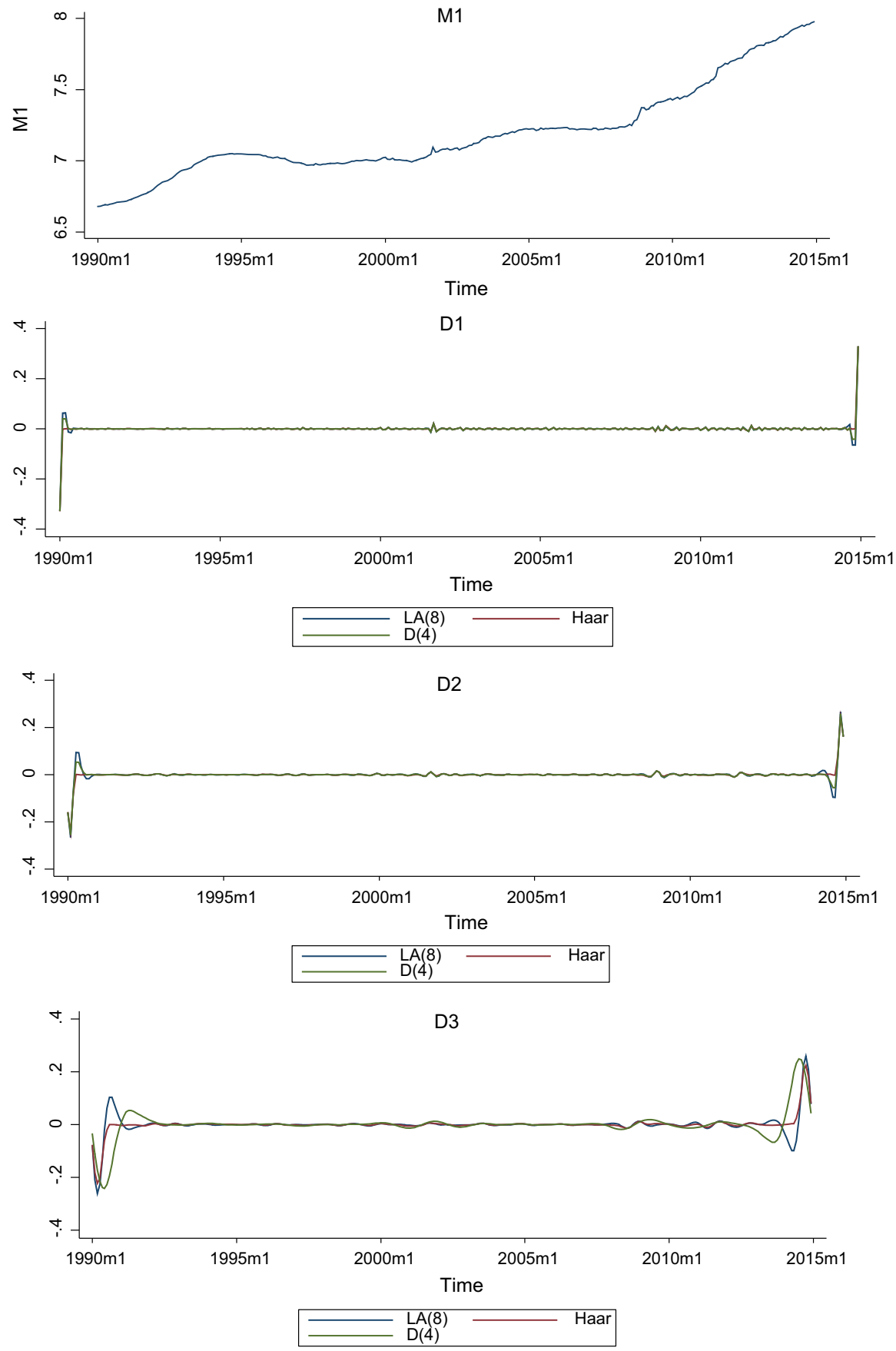

Fig. 2 M1 and its MODWT coefficients, US 

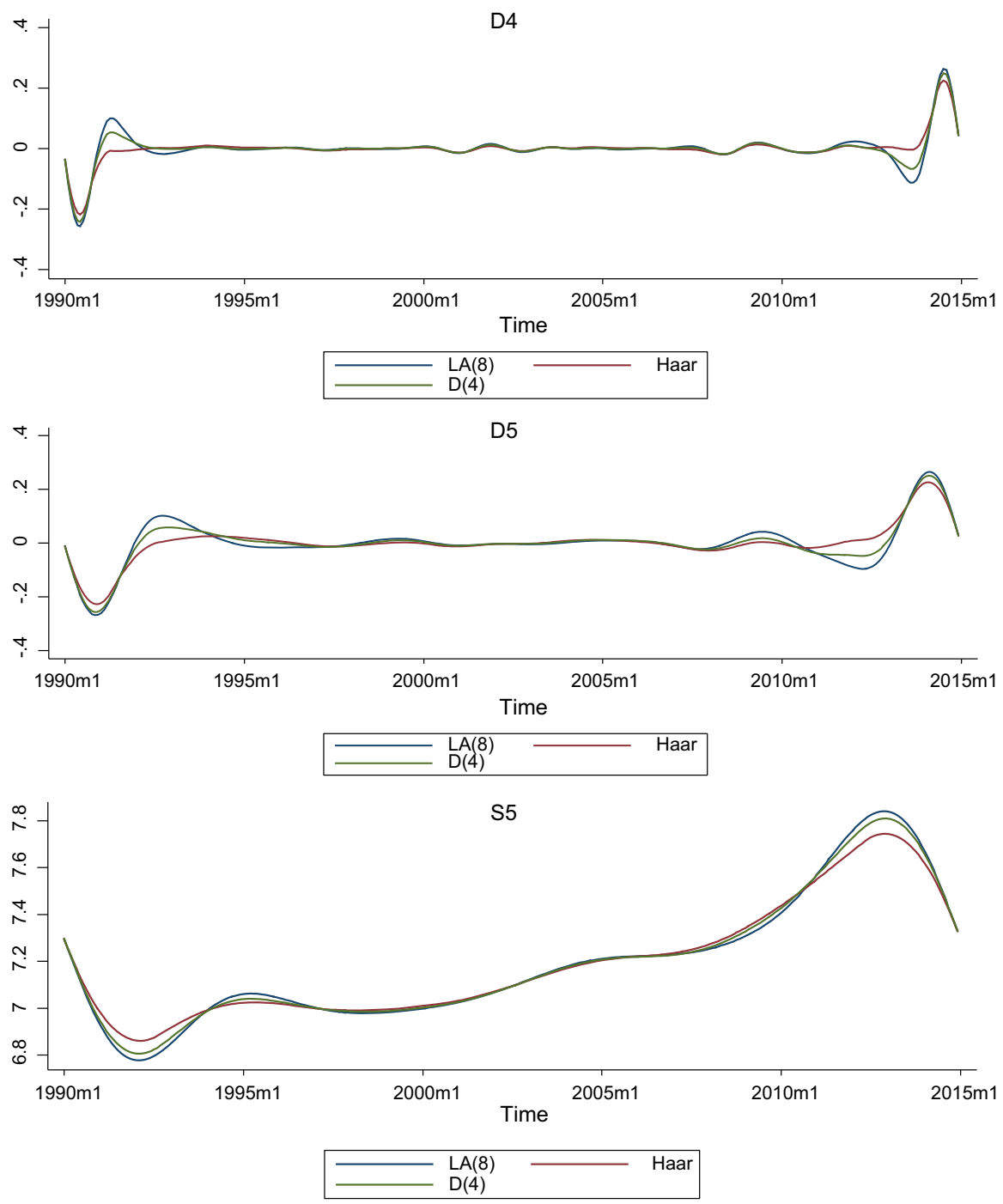

Fig. 2 continued

banks may use interest rate to curb bank credits and ultimately the money stock and inflation, leading to the empirically observed feedback between monetary aggregate and interest rate.

Our findings suggest that the short run is a relative concept and can be shorter than some researchers thought. The failure to recognize that economic agents have different time horizons in time and in space has led to the liquidity puzzle, and decomposing time series into different time horizons solves the puzzle. There is evidence that the short run in the US economy is shorter than in Sweden's, which implies that the policy horizon may be shorter in the US than in Sweden. 


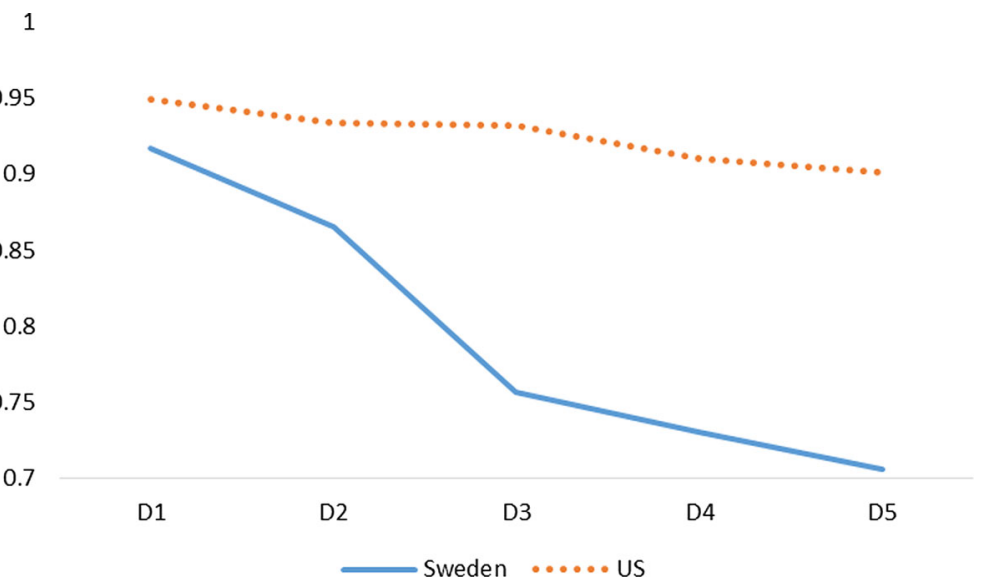

Fig. 3 Multiscale (negative) correlations between money and short-term interest rate

Table 2 Multiscale correlations

\begin{tabular}{llrr}
\hline Time scales & Series & Sweden m & \multicolumn{1}{c}{ US m } \\
\hline D1 & $i$ & $-0.9174^{*}$ & $-0.9489^{*}$ \\
& $y$ & $0.1974^{*}$ & $0.9751^{*}$ \\
D2 & $i$ & $-0.8654^{*}$ & $-0.9338^{*}$ \\
& $y$ & $0.3272^{*}$ & $0.9871^{*}$ \\
D3 & $i$ & $-0.7568^{*}$ & $-0.9320^{*}$ \\
& $y$ & $0.4078^{*}$ & $0.9803^{*}$ \\
D4 & $i$ & $-0.7304^{*}$ & $-0.9107^{*}$ \\
& $y$ & 0.341 & $0.9061^{*}$ \\
D5 & $i$ & $-0.7062^{*}$ & $-0.9013^{*}$ \\
& $y$ & 0.1732 & $0.8799^{*}$ \\
\hline
\end{tabular}

* Significance at $5 \%$. Series are decomposed using the

MODWT-LA(8) wavelet.

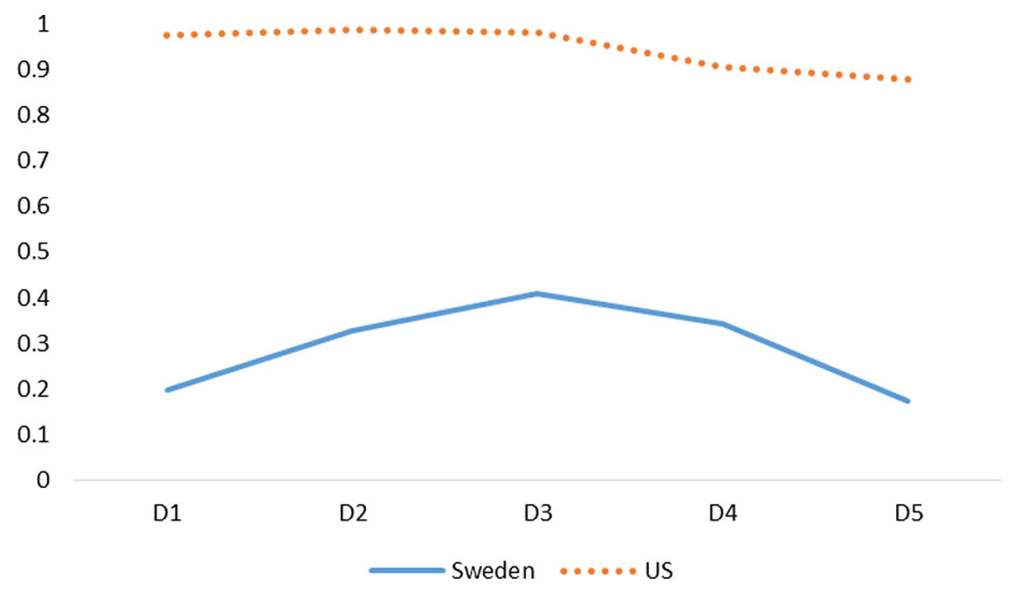

Fig. 4 Multiscale correlations between money and output 
Table 3 Multiscale Granger causality between money and short-term interest rate, based on LA( 8 ) wavelet

\begin{tabular}{|c|c|c|c|c|}
\hline \multirow[t]{2}{*}{ Time scale } & \multicolumn{2}{|l|}{ Sweden } & \multicolumn{2}{|l|}{ US } \\
\hline & $\begin{array}{l}M 1^{\mathrm{a}} \text { does not } \\
\text { Granger cause } i\end{array}$ & $\begin{array}{l}i \text { does not Granger } \\
\text { cause } M 1\end{array}$ & $\begin{array}{l}M 1 \text { does not } \\
\text { Granger cause } i\end{array}$ & $\begin{array}{l}i \text { does not Granger } \\
\text { cause } M 1\end{array}$ \\
\hline D1 & $\begin{array}{l}11.232 * * \\
(0.011)\end{array}$ & $\begin{array}{l}3.0383 \\
(0.386)\end{array}$ & $\begin{array}{l}13.008^{* * *} \\
(0.005)\end{array}$ & $\begin{array}{l}1.633 \\
(0.652)\end{array}$ \\
\hline D2 & $\begin{array}{l}9.7379 * * \\
(0.021)\end{array}$ & $\begin{array}{l}3.0907 \\
(0.378)\end{array}$ & $\begin{array}{l}2.0999 \\
(0.552)\end{array}$ & $\begin{array}{l}1.1604 \\
(0.763)\end{array}$ \\
\hline D3 & $\begin{array}{l}1.1946 \\
(0.754)\end{array}$ & $\begin{array}{l}2.4663 \\
(0.481)\end{array}$ & $\begin{array}{l}20.549^{* * *} \\
(0.000)\end{array}$ & $\begin{array}{l}11.253^{* * *} \\
(0.010)\end{array}$ \\
\hline D4 & $\begin{array}{l}34.573 * * * \\
(0.000)\end{array}$ & $\begin{array}{l}25.137 * * * \\
(0.000)\end{array}$ & $\begin{array}{l}19.452^{* * * *} \\
(0.000)\end{array}$ & $\begin{array}{l}11.555^{* * * *} \\
(0.009)\end{array}$ \\
\hline D5 & $\begin{array}{l}71.44 * * * \\
(0.000)\end{array}$ & $\begin{array}{l}54.57 * * * \\
(0.000)\end{array}$ & $\begin{array}{l}45.277 * * * \\
(0.000)\end{array}$ & $\begin{array}{l}50.817 * * * \\
(0.000)\end{array}$ \\
\hline
\end{tabular}

$*, * *$ and $* * *$ Indicate the rejection of the null hypothesis at the 10,5 and $1 \%$ significance levels, respectively. $P$ values are in parentheses.

a These results still hold when M2 is used instead of M1. This is no surprise since the correlation between M1 and M2 at each wavelet scale is around 0.998 in both economies.

Table 4 Multiscale Granger causality between money and real output, based on LA(8) wavelet

\begin{tabular}{llllll}
\hline \multirow{2}{*}{ Timescale } & \multicolumn{2}{l}{ Sweden } & & US \\
\cline { 2 - 3 } \cline { 5 - 6 } & $\begin{array}{llllll}\text { M1 does not } \\
\text { Granger cause IPI }\end{array}$ & $\begin{array}{l}\text { IPI does not } \\
\text { Granger cause M1 }\end{array}$ & & $\begin{array}{l}\text { M1 does not } \\
\text { Granger cause IPI }\end{array}$ & $\begin{array}{l}\text { IPI does not } \\
\text { Granger cause M1 }\end{array}$ \\
\hline D1 & 1.3695 & $13.591^{* * *}$ & & $7.2674^{*}$ & 2.277 \\
& $(0.713)$ & $(0.004)$ & & $(0.064)$ & $(0.517)$ \\
D2 & 3.8191 & $9.5464^{* *}$ & & 2.9008 & 0.66284 \\
& $(0.282)$ & $(0.023)$ & & $(0.407)$ & $(0.882)$ \\
D3 & 5.1911 & 6.1075 & & $10.398^{* *}$ & $8.5056^{* *}$ \\
& $(0.158)$ & $(0.106)$ & & $(0.015)$ & $(0.037)$ \\
D4 & $6.8227 *$ & $9.7316^{* *}$ & & $6.8788^{*}$ & $6.2894 *$ \\
& $(0.078)$ & $(0.021)$ & & $(0.076)$ & $(0.089)$ \\
D5 & $69.288^{* * *}$ & $103.68^{* * *}$ & & $16.961^{* * *}$ & $6.5675^{*}$ \\
& $(0.000)$ & $(0.000)$ & $(0.001)$ & $(0.087)$ \\
\hline
\end{tabular}

$*, * *$ and $* * *$ Indicate the rejection of the null hypothesis at the 10,5 , and $1 \%$ significance levels, respectively. $P$ values are in parentheses

Results in Table 4 and summarized in Table 5 reveal that there is no evidence of long-run monetary neutrality. For Sweden, causality runs from output to monetary aggregate at the first two wavelet scales. For the US, money Granger causes output at the first wavelet scale. The test is inconclusive at the second and third wavelet scale for the US and Sweden, respectively. At higher scales, from the fourth scale for Sweden and the third scale for the US, there is a feedback between the two variables. 
Table 5 Granger causality at different time horizons (summary), based on LA(8) wavelet

\begin{tabular}{llllll}
\hline Timescale & \multicolumn{2}{l}{ Money and interest rate } & & \multicolumn{2}{l}{ Money and output } \\
\cline { 2 - 3 } \cline { 5 - 6 } & Sweden & US & & Sweden & US \\
\hline D1 & $m \rightarrow i$ & $m \rightarrow i$ & $y \rightarrow m$ & $m \rightarrow y$ \\
D2 & $m \rightarrow i$ & Inconclusive & & $y \rightarrow m$ & Inconclusive \\
D3 & Inconclusive & Feedback & & Inconclusive & Feedback \\
D4 & Feedback & Feedback & & Feedback & Feedback \\
D5 & Feedback & Feedback & & Feedback & Feedback \\
\hline
\end{tabular}

The notation $\rightarrow$ indicates the direction of Granger causality. Inconclusive means that neither null hypothesis (see Tables 3, 4) is rejected. Feedback implies that both hypotheses are rejected

Table 6 Multiscale Granger causality between money and short-term interest rate (summary), based on Haar and D(4) wavelets

\begin{tabular}{|c|c|c|c|c|}
\hline \multirow[t]{2}{*}{ Timescale } & \multicolumn{2}{|l|}{ Haar } & \multicolumn{2}{|l|}{$\mathrm{D}(4)$} \\
\hline & Sweden & US & Sweden & US \\
\hline D1 & Inconclusive & $m \rightarrow i$ & $m \rightarrow i$ & $m \rightarrow i$ \\
\hline D2 & $m \rightarrow i$ & $m \rightarrow i$ & $m \rightarrow i$ & Inconclusive \\
\hline D3 & $m \rightarrow i$ & Inconclusive & Inconclusive & $m \rightarrow i$ \\
\hline D4 & $m \rightarrow i$ & $m \rightarrow i$ & Feedback & Feedback \\
\hline D5 & Feedback & Feedback & Feedback & Feedback \\
\hline
\end{tabular}

The notation $\rightarrow$ indicates the direction of Granger causality. Inconclusive means that neither null hypothesis (see Tables 8,9$)$ is rejected. Feedback implies that both hypotheses are rejected

\subsection{Robustness Checks}

The results discussed so far are based on the LA(8) wavelet. In this section, we investigate the extent to which the main findings are sensitive to the type and length of the wavelet. Accordingly, Granger causality between money and interest rate, and money and output is re-examined based on detail coefficients that are obtained using Haar and $\mathrm{D}(4)$ father $(\phi)$ and mother $(\psi)$ wavelets. Table 6 summarizes Granger causality tests between money and interest rate. Results that are based on Haar wavelet indicate that money Granger causes interest rate at the second, third and fourth scales for Sweden, and at the first, second and fourth scales for the US. The test is inconclusive at the first scale for Sweden and at the third scale for the US. There is a feedback mechanism at the highest scale (low-frequency) scale D5. Overall, compared to the main results, the direction of causality does not change, but there are some differences at the first four scales. These differences across scales are not surprising since Haar wavelet has small support $(L=2)$ compared to $\mathrm{LA}(8)$ wavelet $(\mathrm{L}=8)$. As Gençay et al. (2010) points out, shorter wavelet filters may not be able to separate the activity between scales, especially when the spectral density function of the series is quite dynamic. Moreover, the LA(8) scaling coefficients carry relatively more information 
Table 7 Multiscale Granger causality between money and output (summary), based on Haar and D(4) wavelets

\begin{tabular}{|c|c|c|c|c|}
\hline \multirow[t]{2}{*}{ Timescale } & \multicolumn{2}{|l|}{ Haar } & \multicolumn{2}{|l|}{$\mathrm{D}(4)$} \\
\hline & Sweden & US & Sweden & US \\
\hline D1 & $y \rightarrow m$ & $m \rightarrow y$ & $y \rightarrow m$ & $m \rightarrow y$ \\
\hline D2 & $y \rightarrow m$ & Inconclusive & $y \rightarrow m$ & Inconclusive \\
\hline D3 & Inconclusive & Inconclusive & Inconclusive & Inconclusive \\
\hline D4 & Feedback & Feedback & Feedback & Feedback \\
\hline D5 & Feedback & Feedback & Feedback & Feedback \\
\hline
\end{tabular}

The notation $\rightarrow$ indicates the direction of Granger causality. Inconclusive means that neither null hypothesis (see Tables 10, 11) is rejected. Feedback implies that both hypotheses are rejected

Table 8 Multiscale Granger causality between money and short-term interest rate, based on Haar wavelet

\begin{tabular}{|c|c|c|c|c|}
\hline \multirow[t]{2}{*}{ Time scale } & \multicolumn{2}{|l|}{ Sweden } & \multicolumn{2}{|l|}{ US } \\
\hline & $\begin{array}{l}M 1 \text { does not } \\
\text { Granger cause } i\end{array}$ & $\begin{array}{l}i \text { does not Granger } \\
\text { cause } M 1\end{array}$ & $\begin{array}{l}M 1 \text { does not } \\
\text { Granger cause } i\end{array}$ & $\begin{array}{l}i \text { does not Granger } \\
\text { cause } M 1\end{array}$ \\
\hline D1 & $\begin{array}{l}2.299 \\
(0.513)\end{array}$ & $\begin{array}{l}0.997 \\
(0.802)\end{array}$ & $\begin{array}{l}6.597 * \\
(0.073)\end{array}$ & $\begin{array}{l}0.089 \\
(0.993)\end{array}$ \\
\hline D2 & $\begin{array}{l}19.787 * * * \\
(0.000)\end{array}$ & $\begin{array}{l}0.44075 \\
(0.932)\end{array}$ & $\begin{array}{l}8.508 * * \\
(0.037)\end{array}$ & $\begin{array}{l}0.81104 \\
(0.847)\end{array}$ \\
\hline D3 & $\begin{array}{l}9.227 * * \\
(0.026)\end{array}$ & $\begin{array}{l}0.058 \\
(0.996)\end{array}$ & $\begin{array}{l}3.579 \\
(0.311)\end{array}$ & $\begin{array}{l}0.832 \\
(0.842)\end{array}$ \\
\hline D4 & $\begin{array}{l}8.309 * * \\
(0.040)\end{array}$ & $\begin{array}{l}1.0391 \\
(0.792)\end{array}$ & $\begin{array}{l}9.501 * * \\
(0.023)\end{array}$ & $\begin{array}{l}2.723 \\
(0.436)\end{array}$ \\
\hline D5 & $\begin{array}{l}10.749 * * \\
(0.013)\end{array}$ & $\begin{array}{l}8.416 * * \\
(0.039)\end{array}$ & $\begin{array}{l}10.703 * * \\
(0.013)\end{array}$ & $\begin{array}{l}6.887 * \\
(0.070)\end{array}$ \\
\hline
\end{tabular}

$*, * *$ and $* * *$ Indicate the rejection of the null hypothesis at the 10,5 and $1 \%$ significance levels, respectively. $P$ values are in parentheses

due to the increased filter width, and the filter is more capable to isolate features to specific frequency intervals (Chen et al. 2017).

Results that are based on the $\mathrm{D}(4)$ wavelet indicate that the causality runs from money to interest rate at lower and medium scales, and there is a feedback mechanism at higher scales. Overall, these findings are in line with the main findings; the liquidity effect is significant in both economies (Table 6).

Table 7 present the results of the Granger causality tests between money and output, applied on detail coefficients that are based on Haar and $\mathrm{D}(4)$ wavelets. The results indicate that causality runs from output to money at the first two wavelet scales for Sweden, and from money to output at the first wavelet scale for the US. At higher scales, D4 and D5, there is a feedback between the two variables. These findings, in line with the main findings that are based on the LA(8) wavelet, suggest that there is no evidence of long-run monetary neutrality in both economies. 
Table 9 Multiscale Granger causality between money and short-term interest rate, based on D(4) wavelet

\begin{tabular}{|c|c|c|c|c|}
\hline \multirow[t]{2}{*}{ Time scale } & \multicolumn{2}{|l|}{ Sweden } & \multicolumn{2}{|l|}{ US } \\
\hline & $\begin{array}{l}M 1 \text { does not } \\
\text { Granger cause } i\end{array}$ & $\begin{array}{l}i \text { does not Granger } \\
\text { cause } M 1\end{array}$ & $\begin{array}{l}M 1 \text { does not } \\
\text { Granger cause } i\end{array}$ & $\begin{array}{l}i \text { does not Granger } \\
\text { cause } M 1\end{array}$ \\
\hline D1 & $\begin{array}{l}36.009 * * * \\
(0.000)\end{array}$ & $\begin{array}{l}4.846 \\
(0.183)\end{array}$ & $\begin{array}{l}46.152 * * * \\
(0.000)\end{array}$ & $\begin{array}{l}1.5184 \\
(0.678)\end{array}$ \\
\hline D2 & $\begin{array}{l}10.68 * * \\
(0.014)\end{array}$ & $\begin{array}{l}0.948 \\
(0.814)\end{array}$ & $\begin{array}{l}2.712 \\
(0.438)\end{array}$ & $\begin{array}{l}0.977 \\
(0.807)\end{array}$ \\
\hline D3 & $\begin{array}{l}1.684 \\
(0.641)\end{array}$ & $\begin{array}{l}0.783 \\
(0.783)\end{array}$ & $\begin{array}{l}6.787 * \\
(0.079)\end{array}$ & $\begin{array}{l}2.4992 \\
(0.475)\end{array}$ \\
\hline D4 & $\begin{array}{l}23.760 * * * \\
(0.000)\end{array}$ & $\begin{array}{l}11.862 * * * \\
(0.008)\end{array}$ & $\begin{array}{l}12.675^{* * *} \\
(0.005)\end{array}$ & $\begin{array}{l}6.455^{*} \\
(0.091)\end{array}$ \\
\hline D5 & $\begin{array}{l}61.582 * * * \\
(0.000)\end{array}$ & $\begin{array}{l}40.240 * * * \\
(0.000)\end{array}$ & $\begin{array}{l}23.907 * * * \\
(0.000)\end{array}$ & $\begin{array}{l}19.165^{* * * *} \\
(0.000)\end{array}$ \\
\hline
\end{tabular}

See notes under Table 8

Table 10 Multiscale Granger causality between money and real output, based on Haar wavelet

\begin{tabular}{|c|c|c|c|c|}
\hline \multirow[t]{2}{*}{ Timescale } & \multicolumn{2}{|l|}{ Sweden } & \multicolumn{2}{|l|}{ US } \\
\hline & $\begin{array}{l}\text { M1 does not } \\
\text { Granger cause IPI }\end{array}$ & $\begin{array}{l}\text { IPI does not } \\
\text { Granger cause M1 }\end{array}$ & $\begin{array}{l}\text { M1 does not } \\
\text { Granger cause IPI }\end{array}$ & $\begin{array}{l}\text { IPI does not } \\
\text { Granger cause M1 }\end{array}$ \\
\hline D1 & $\begin{array}{l}0.373 \\
(0.946)\end{array}$ & $\begin{array}{l}8.523 * * \\
(0.036)\end{array}$ & $\begin{array}{l}10.79 * * \\
(0.012)\end{array}$ & $\begin{array}{l}3.635 \\
(0.304)\end{array}$ \\
\hline D2 & $\begin{array}{l}3.881 \\
(0.275)\end{array}$ & $\begin{array}{l}6.853 * \\
(0.077)\end{array}$ & $\begin{array}{l}0.622 \\
(0.892)\end{array}$ & $\begin{array}{l}1.315 \\
(0.725)\end{array}$ \\
\hline D3 & $\begin{array}{l}1.861 \\
(0.602)\end{array}$ & $\begin{array}{l}0.7022 \\
(0.873)\end{array}$ & $\begin{array}{l}2.164 \\
(0.539)\end{array}$ & $\begin{array}{l}0.457 \\
(0.928)\end{array}$ \\
\hline D4 & $\begin{array}{l}12.523 * * * \\
(0.006)\end{array}$ & $\begin{array}{l}6.887 * \\
(0.073)\end{array}$ & $\begin{array}{l}8.518 * * \\
(0.039)\end{array}$ & $\begin{array}{l}9.601 * * \\
(0.033)\end{array}$ \\
\hline D5 & $\begin{array}{l}9.588 * * \\
(0.047)\end{array}$ & $\begin{array}{l}6.625 * \\
(0.0775)\end{array}$ & $\begin{array}{l}20.787 * * * \\
(0.000)\end{array}$ & $\begin{array}{l}11.08 * * \\
(0.013)\end{array}$ \\
\hline
\end{tabular}

See notes under Table 8

Table 11 Multiscale Granger causality between money and real output, based on (D4) wavelet

\begin{tabular}{llllll}
\hline Timescale & \multicolumn{2}{l}{ Sweden } & & US \\
\cline { 2 - 3 } \cline { 5 - 6 } & $\begin{array}{l}\text { M1 does not } \\
\text { Granger cause IPI }\end{array}$ & $\begin{array}{l}\text { IPI does not } \\
\text { Granger cause M1 }\end{array}$ & & $\begin{array}{l}\text { M1 does not } \\
\text { Granger cause IPI }\end{array}$ & $\begin{array}{l}\text { IPI does not } \\
\text { Granger cause M1 }\end{array}$ \\
\hline D1 & 1.372 & $11.18^{* *}$ & $21.366^{* * *}$ & 3.445 \\
& $(0.712)$ & $(0.011)$ & & $(0.000)$ & $(0.328)$ \\
D2 & 4.927 & $7.966^{* *}$ & 3.181 & 0.504 \\
& $(0.177)$ & $(0.047)$ & & $(0.365)$ & $(0.918)$ \\
\hline
\end{tabular}


Table 11 continued

\begin{tabular}{|c|c|c|c|c|}
\hline \multirow[t]{2}{*}{ Timescale } & \multicolumn{2}{|l|}{ Sweden } & \multicolumn{2}{|l|}{ US } \\
\hline & $\begin{array}{l}\text { M1 does not } \\
\text { Granger cause IPI }\end{array}$ & $\begin{array}{l}\text { IPI does not } \\
\text { Granger cause M1 }\end{array}$ & $\begin{array}{l}\text { M1 does not } \\
\text { Granger cause IPI }\end{array}$ & $\begin{array}{l}\text { IPI does not } \\
\text { Granger cause M1 }\end{array}$ \\
\hline D3 & $\begin{array}{l}2.751 \\
(0.432)\end{array}$ & $\begin{array}{l}3.1529 \\
(0.369)\end{array}$ & $\begin{array}{l}3.368 \\
(0.338)\end{array}$ & $\begin{array}{l}1.779 \\
(0.619)\end{array}$ \\
\hline D4 & $\begin{array}{l}14.8 * * * \\
(0.002)\end{array}$ & $\begin{array}{l}28.452 * * * \\
(0.000)\end{array}$ & $\begin{array}{l}6.987 * \\
(0.069)\end{array}$ & $\begin{array}{l}10.89 * * \\
(0.011)\end{array}$ \\
\hline D5 & $\begin{array}{l}22.08 * * * \\
(0.000)\end{array}$ & $\begin{array}{l}29.364 * * * \\
(0.000)\end{array}$ & $\begin{array}{l}10.921 * * \\
(0.012)\end{array}$ & $\begin{array}{l}16.006^{* * *} \\
(0.000)\end{array}$ \\
\hline
\end{tabular}

See notes under Table 8
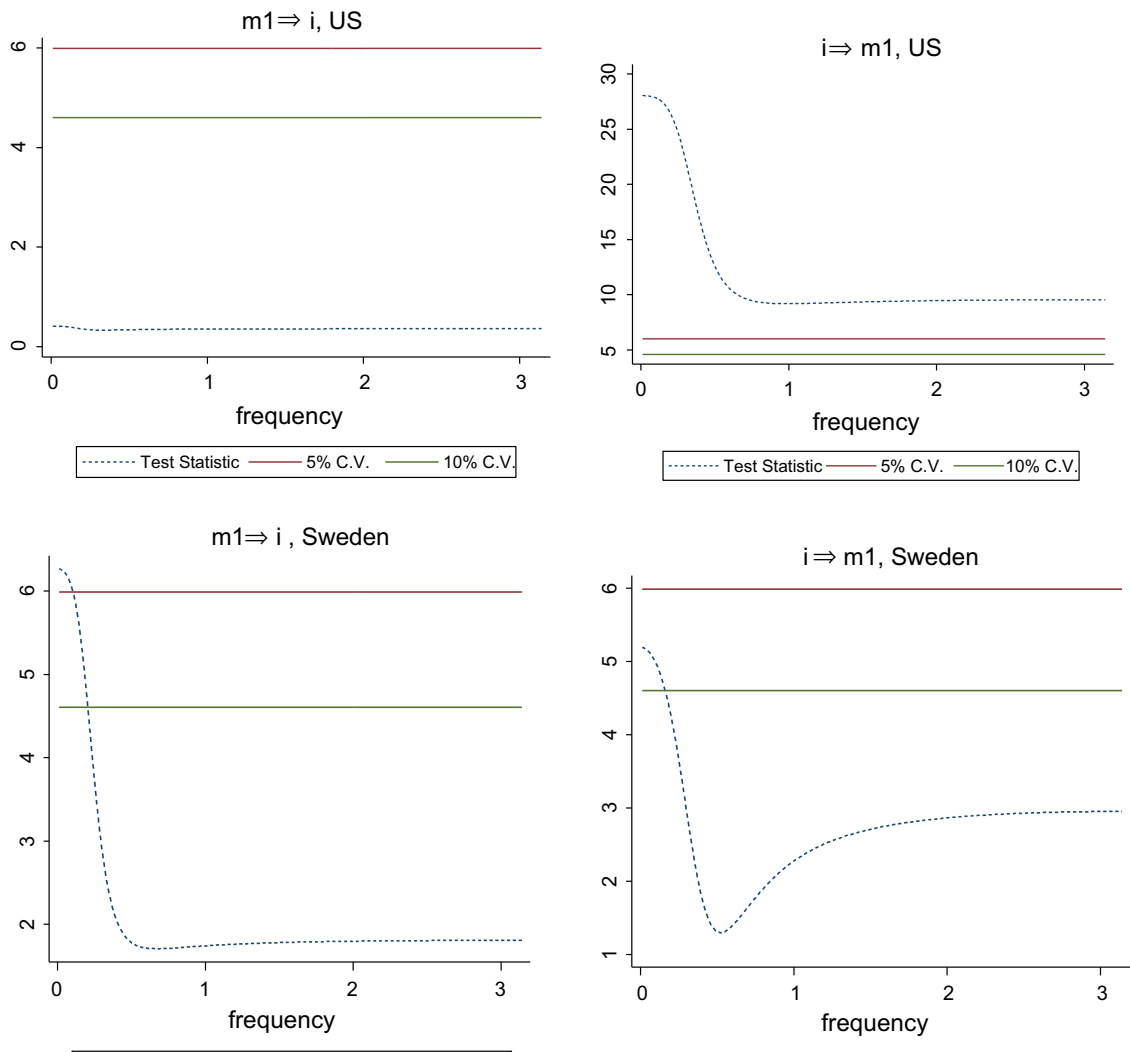

$-\cdots+\cdots$ Test Statistic $-5 \%$ C.V. $-10 \%$ C.V.

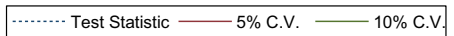

Fig. 5 Spectral Granger causality between interest rate and monetary aggregate, US and Sweden. Notes: The horizontal axis shows the frequency ordinates in the interval $(0, \pi)$. The vertical axis shows the test statistics. The lines parallel to the frequency axis represents the critical value for the null hypothesis, at 10 and $5 \%$ levels of significance. The dotted line indicates the test statistic at each frequency 


\subsection{Comparison with Spectral Analysis}

Wavelet analysis is an improvement over spectral analysis. Wavelet analysis can capture events that are local in time and in frequency, unlike frequency-domain (spectral) analysis that can only keep the information on frequencies, and the time information is lost. In this section, for comparison, Granger causality between money and short-term interest rate, and money and output is investigated across frequencies using spectral Granger causality test (see Breitung and Candelon 2006).

Figure 5 plots spectral Granger causality between interest rate and money for both the US and Sweden. At a 5\% significance level, the test suggests that interest rate Granger causes money supply in the US economy, and neither variable causes the other in Sweden's economy. Thus, spectral analysis suggests that there is no evidence of liquidity effect in both economies.
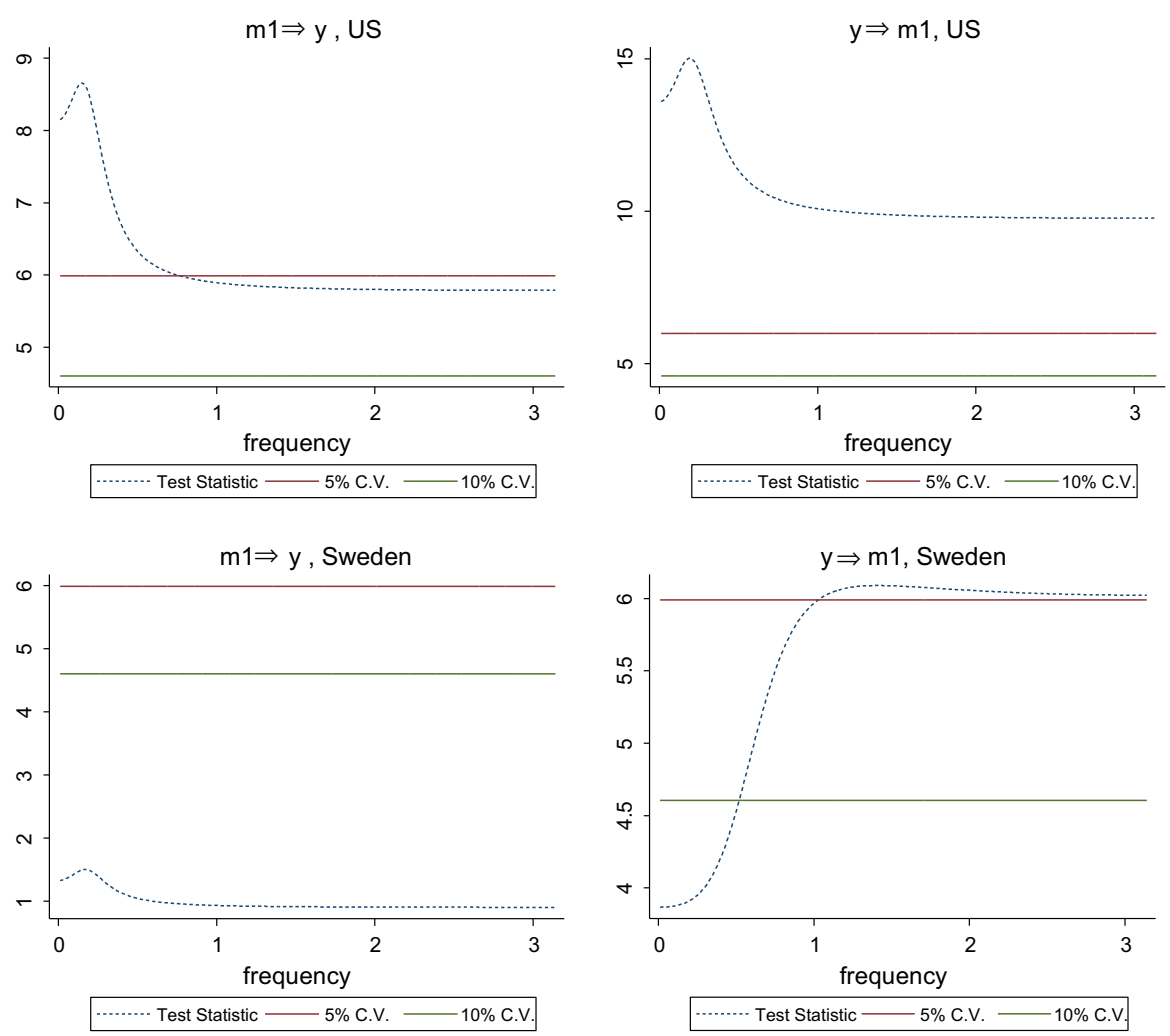

Fig. 6 Spectral Granger causality between interest rate and monetary aggregate, US and Sweden. Notes: The horizontal axis shows the frequency ordinates in the interval $(0, \pi)$. The vertical axis shows test statistics. The lines parallel to the frequency axis represents the critical value for the null hypothesis, at 10 and $5 \%$ level of significance. The dotted line indicates the test statistic at each frequency 
Figure 6 shows that for the US economy money Granger causes output in the lower frequency band, and output Granger causes money at all frequencies. Thus, there is a feedback between the two variables. For Sweden, output Granger causes money at intermediate and high frequency, and there is no feedback.

It is not surprising that the frequency domain and the time-frequency domain (wavelet) analyses give different results. Each of the variables in this study is non stationary in levels (see Table 12 in "Appendix"), which implies that the frequency structure of the series evolves over time, and requires, therefore, a transform that can simultaneously capture time and frequency localizations. Thus, the wavelet transform is more appropriate.

\section{Conclusion}

In this study, two propositions in monetary economics-liquidity effect and longrun monetary neutrality - are investigated using monthly series of Sweden and the US. We employ wavelets to decompose short-term interest rate, monetary aggregate and output into different timescales to assess their relationship across different cyclical movements. Accordingly, series are decomposed into five timescales using the MODWT with LA (8), D(4) and Haar wavelets. Evidence from both multiscale correlations and Granger causality suggests that the liquidity effect is statistically significant in both economies, with shorter horizons in the US than in Sweden. There is no evidence of long-run monetary neutrality in both economies. Monetary disturbances have significant real effects, and these effects last longer than it is assumed in RBC models.

Acknowledgements The author is grateful to anonymous referees for their insightful comments and suggestions that markedly improved this paper.

Open Access This article is distributed under the terms of the Creative Commons Attribution 4.0 International License (http://creativecommons.org/licenses/by/4.0/), which permits unrestricted use, distribution, and reproduction in any medium, provided you give appropriate credit to the original author(s) and the source, provide a link to the Creative Commons license, and indicate if changes were made.

\section{Appendix}

\section{A. Unit Root Test}

In Sect. 4.5 we claim that the series are nonstationary. The null hypothesis of a random walk is tested using the DF-GLS unit root test. The DF-GLS (see Elliott et al. 1996) consists of two steps. First, the time series is transformed (de-trended) via a generalized least squares (GLS) regression. Second, the usual augmented Dickey-Fuller test is performed on GLS-detrended data. Through Monte Carlo simulations, Elliott et al. argue that the DF-GLS test is more efficient, especially when an unknown mean or trend is present in the series. Results in Table 12 indicate that $M 1, i$, and $y$ are $\mathrm{I}(1)$. 
Table 12 Unit root test results

\begin{tabular}{llr}
\hline Series & Sweden & US \\
\hline $\mathrm{m}$ & $-2.134(1)$ & $-0.388(3)$ \\
$\mathrm{i}$ & $-2.597(1)$ & $-2.399(3)$ \\
$\mathrm{y}$ & $-1.185(1)$ & $-1.686(4)$ \\
$\Delta \mathrm{m}$ & $-3.58^{* * *(3)}$ & $-6.307 * * *(2)$ \\
$\Delta \mathrm{i}$ & $-4.706 * * *(1)$ & $-5.556 * * *(2)$ \\
$\Delta \mathrm{y}$ & $-5.063 * *(3)$ & $-4.006 * * *(3)$ \\
\hline
\end{tabular}

$\Delta$ denotes the first difference. $*, * *$ and $* * *$ indicate rejection of the null hypothesis at 10,5 and $1 \%$ significance levels, respectively. The lag length is in parentheses and is based on Schwert (1989) criterion

\section{B. Computation of the MODWT Coefficients}

This is a follow up to Sect. 3.2. The MODWT wavelet and scaling coefficients are computed using the Pyramid algorithm (Mallat 1989). The algorithm uses two types of filters: the wavelet (high-pass) filter and the scaling (low-pass) filter. The MODWT acts like the DWT, but, unlike the latter, does not suffer from downsampling (Percival and Walden 2006, p. 164). Accordingly, the MODWT wavelet and scaling filters, $\tilde{h}_{j}$ and $\tilde{g}_{j}$ are the rescaled versions of DWT filters, $h_{j}$ and $g_{j}$ to circumvent the dyadic length requirement (i.e., a sample size divisible by $2^{\mathrm{J}}$ ) of the DWT (see Gençay et al. 2002, p. 122), as follows:

$$
\tilde{h}_{j}=h_{j} / 2^{j} \text { and } \tilde{g}_{J}={ }^{g_{J}} / 2^{J}, \quad j=1,2, \ldots, J
$$

The algorithm consists of iterations, and requires three objects: the data vector $X$, the wavelet filter $\tilde{h}_{j}$ and the scaling filter $\tilde{g}_{j}$.

Consider $X_{t}$, a time series of $t=0,1, \ldots, N-1$ observations. The filtering process takes several steps as follows.

Step $1 X_{t}$ is filtered to obtain first-level $(j=1)$ wavelet $\left(\tilde{w}_{1}\right)$ and scaling coefficients $\left(\tilde{v}_{1}\right)$ using the wavelet $\left(\tilde{h}_{l}\right)$ filter and scaling $\left(\tilde{g}_{l}\right)$ filter, respectively as follows:

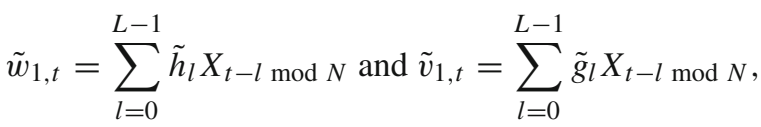

$$
\begin{aligned}
& t=0,1, \ldots, N-1 ; \quad l=0,1, \ldots, L-1
\end{aligned}
$$

where $L$ denotes the length of the wavelet filter.

Step 2 The algorithm filters first-level scaling coefficients $\left(\tilde{v}_{1, t}\right)$ to obtain second-level $(j=2)$ wavelet and scaling coefficients, respectively as follows:

$$
\begin{gathered}
\tilde{w}_{2, t}=\sum_{l=0}^{L-1} \tilde{h}_{l} \tilde{v}_{1, t-l \bmod N} \text { and } \tilde{v}_{2, t}=\sum_{l=0}^{L-1} \tilde{g}_{l} \tilde{v}_{1, t-l \bmod N}, \\
\quad t=0,1, \ldots, N-1 ; \quad l=0,1, \ldots, L-1
\end{gathered}
$$


Step $j$ The procedure is repeated to get the $\mathrm{j}$-th level wavelet and scaling MODWT coefficients, respectively as follows:

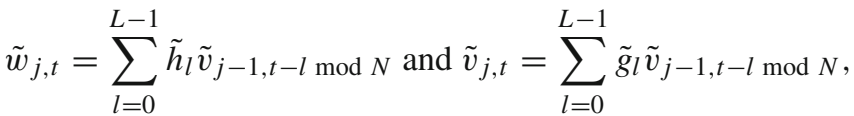

$$
\begin{aligned}
& t=0,1, \ldots, N-1 ; \quad l=0,1, \ldots, L-1 ; \quad j=1,2, \ldots, J
\end{aligned}
$$

where $J \leq \log _{2}(N)$ is the highest level of decomposition.

Finally, we obtain a vector $\tilde{W}$ that consists of $\mathrm{J}+1$ sub-vectors of dimension $\mathrm{N}$, as follows:

$$
\tilde{W}=\left[\begin{array}{lllll}
\tilde{W}_{1} & \tilde{W}_{2} \ldots \tilde{W}_{J} & \tilde{V}_{J}
\end{array}\right]^{T} \quad j=1,2, \ldots, J
$$

where the first $\mathbf{J}$ sub-vectors contain the MODWT wavelet coefficients for $j=$ $1,2, \ldots, J$, and the last sub-vector contains the MODWT scaling coefficients at the highest level of decomposition $\mathrm{J}$; the superscript $\mathrm{T}$ denotes the transpose.

\section{References}

Andersen, L., \& Jordan, J. (1968). Monetary and fiscal actions: a test of their relative importance in economic stabilization. Federal Reserve Bank of St. Louis Review, 50, 11-24.

Andersson, F. N. (2008). Wavelet analysis of economic time series. Lund Economic Studies, 149.

Bagliano, F. C., \& Favero, C. A. (1998). Measuring monetary policy with VAR models: an evaluation. European Economic Review, 42, 1069-1112.

Berger, H., \& Österholm, P. (2009). Does money still matter for US output? Economics Letters, 102, $143-146$.

Bernanke, B. S., \& Blinder, A. S. (1992). The federal funds rate and the channels of monetary transmission. American Economic Review, 82, 901-921.

Bernanke, B. S., \& Mihov, I. (1998). Measuring monetary policy. Quarterly Journal of Economics, 113, 869-902.

Bernanke, B. S., Boivin, J., \& Eliasz, P. (2005). Measuring the effects of monetary policy: A factoraugmented vector autoregressive (FAVAR) approach. The Quarterly Journal of Economics, 120(1), $387-422$.

Breitung, J., \& Candelon, B. (2006). Testing for short-and long-run causality: A frequency-domain approach. Journal of Econometrics, 132(2), 363-378.

Canova, F., \& Menz, T. (2011). Does money matter in shaping domestic business cycles? An international investigation. Journal of Money, Credit \& Banking, 43(4), 577-607.

Chen, Y. T., Sun, E. W., \& Yu, M. T. (2017). Risk assessment with wavelet feature engineering for highfrequency portfolio trading. Computational Economics. doi:10.1007/s10614-017-9711-7.

Christiano, L. J. (1991). Modeling the liquidity effect of a money shock. Federal Reserve Bank of Minneapolis Quarterly Review, 15(1), 3-34.

Christiano, L. J., \& Ljungqvist, L. (1988). Money does Granger-cause output in the bivariate money-output relation. Journal of Monetary Economics, 22, 217-235.

Cochrane, J. (1989). The return of the liquidity effect: A study of the short-run relation between money growth and interest rates. Journal of Business and Economic Statistics, 7, 75-83.

Cornish, C. R., Bretherton, C. S., \& Percival, D. B. (2006). Maximal overlap wavelet statistical analysis with application to atmospheric turbulence. Boundary-Layer Meteorology, 119(2), 339-374.

Daubechies, I. (1988). Orthonormal bases of compactly supported wavelets. Communications on Pure and Applied Mathematics, 41(7), 909-996.

Daubechies, I. (1992). Ten Lectures on Wavelets, Volume 61 of CBMS-NSF Regional Conference Series in Applied Mathematics. Society for Industrial and Applied Mathematics, Philadelphia. 
Dolado, J., \& Lütkepohl, H. (1996). Making Wald tests work for cointegrated VAR systems. Econometric Reviews, 15, 369-386.

Eichenbaum, M. (1992). Comments on "Interpreting the macroeconomic time series facts: The effects of monetary policy” by C. Sims. European Economic Review, 36, 1001-1011.

Elliott, G., Rothenberg, T., \& Stock, J. H. (1996). Efficient tests for an autoregressive unit root. Econometrica, 64, 813-836.

Engle, R. F., \& Granger, C. W. J. (1987). Co-integration and error correction: Representation, estimation and testing. Econometrica, 55, 251-276.

Fisher, M., \& Seater, J. (1993). Long-run neutrality and superneutrality in an ARIMA framework. American Economic Review, 83, 402-415.

Friedman, B. M., \& Kuttner, K. N. (1993). Another look at the evidence on money-income causality. Journal of Econometrics, 57(1-3), 189-203.

Gali, J. (1992). How well does the IS-LM model fit postwar U.S. data? Quarterly Journal of Economics, 107(2), 709-738.

Gençay, R., Gradojevic, N., Selçuk, F., \& Whitcher, B. (2010). Asymmetry of information flow between volatilities across time scales. Quantitative Finance, 10(8), 895-915.

Gençay, R., Selçuk, F., \& Whitcher, B. (2002). An introduction to wavelets and other filtering methods in finance and economics. New York: Academic Press.

Granger, C. W. J. (1969). Investigating causal relation by econometric and cross-sectional method. Econometrica, 37, 424-438.

Haar, A. (1910). Zur Theorie der orthogonalen Funktionensysteme. Mathematische Annalen, 69(3), 331-71.

Hafer, R. W., \& Jansen, D. W. (1991). The demand for money in the United States: Evidence from cointegrating tests. Journal of Money, Credit and Banking, 23, 155-168.

Kelly, L. J., Barnett, W. A., \& Keating, J. W. (2011). Rethinking the liquidity puzzle: Application of a new measure of the economic money stock. Journal of Banking and Finance, 35(4), 768-774.

Koustas, Z. (1998). Canadian evidence on long-run neutrality propositions. Journal of Macroeconomics, 20, 397-411.

Lee, J. (2012). Nonparametric testing for long-run neutrality with applications to US money and output data. Computational Economics, 40(2), 183-202.

Leeper, E. M., \& Gordon, D. B. (1992). In search of the liquidity effect. Journal of Monetary Economics, 29, 341-370.

Lo, M. C., \& Piger, J. (2005). Is the response of output to monetary policy asymmetric? Evidence from a regime-switching coefficients model. Journal of Money, Credit \& Banking, 37, 865-886.

Lucas, R. (1996). Nobel lecture: Monetary neutrality. Journal of Political Economy, 104(4), 661-682.

Mallat, S. G. (1989). A theory for multiresolution signal decomposition: The wavelet representation. IEEE Transactions on Pattern Analysis and Machine Intelligence, 11(7), 674-693.

Melvin, M. (1983). The vanishing liquidity effect of money on interest: Analysis and implications for policy. Economic Inquiry, 21(2), 188-202.

Michis, A. (2015). Multiscale analysis of the liquidity effect in the UK economy. Computational Economics, 45(4), 615-633.

Mishkin, F. S. (1982). Monetary policy and short term interest rates: An efficient markets-rational expectations approach. Journal of Finance, 37(1), 63-72.

Noriega, A. E., Soria, L. M., \& Velázquez, R. (2008). International evidence on stochastic and deterministic monetary neutrality. Economic Modelling, 25(6), 1261-1275.

Park, J. Y., \& Phillips, P. C. B. (1989). Statistical inference in regressions with integrated processes: Part 2. Econometric Theory, 5(1), 95-132.

Percival, D. B., \& Mofjeld, H. O. (1997). Analysis of subtidal coastal sea level fluctuations using wavelets. Journal of American Statistical Association, 92(439), 868-880.

Percival, D. B., \& Walden, A. T. (2006). Wavelet methods for time series analysis (Vol. 4). Cambridge: Cambridge University Press.

Psaradakis, Z., Ravn, M. O., \& Sola, M. (2005). Markov switching causality and the money-output relationship. Journal of Applied Economics, 20(5), 665-683.

Ramsey, J. B. (2002). Wavelets in economics and finance: Past and future. Studies in Nonlinear Dynamics \& Econometrics, 6(3), 1-29.

Ramsey, J. B., \& Lampart, C. (1998). Decomposition of economic relationships by timescale using wavelets. Macroeconomic dynamics, 2(01), 49-71.

Romer, D. (2012). Advanced macroeconomics (4th ed.). New York: McGraw-Hill. 
Rudebusch, G. (1998). Do measures of monetary policy shocks in a VAR make sense? International Economic Review, 39(4), 907-941.

Schwert, G. W. (1989). Tests for unit roots: A Monte Carlo investigation. Journal of Business \& Economic Statistics, 7, 147-160.

Scott Hacker, R., Karlsson, H. K., \& Månsson, K. (2012). The relationship between exchange rates and interest rate differentials: a wavelet approach. The World Economy, 35(9), 1162-1185.

Serletis, A., \& Chwee, V. (1997). Resolving the liquidity puzzle. Macroeconomic Dynamics, 1(4), 720-739.

Sims, C. A. (1972). Money, income and causality. American Economic Review, 62, 540-552.

Sims, C. A. (1986). Are forecasting models usable for policy analysis? Quarterly Review, 10(1), 2-16.

Sims, C. A. (1992). Interpreting the macroeconomic time series facts: The effects of monetary policy. European Economic Review, 36(5), 975-1000.

Sims, C. A., Stock, J. H., \& Watson, M. W. (1990). Inference in linear time series models with some unit roots. Econometrica, 58(1), 113-144.

Sjölander, P., Shukur, G., Månsson, K., \& Kekezi, O. (2015). The efficiency of the Scandinavian banking sector-a wavelet quantile regression analysis. Applied Economics, 47(50), 5378-5389.

Swanson, N. R. (1998). Money and output viewed through a rolling window. Journal of Monetary Economics, 41(3), 455-474.

Thoma, M. A. (1994). Subsample instability and asymmetries in money-income causality. Journal of Econometrics, 64(2), 279-306.

Toda, H. Y., \& Yamamoto, T. (1995). Statistical inferences in vector autoregressions with possibly integrated processes. Journal of Econometrics, 66(1-2), 225-250.

Ventosa-Santaulària, D., \& Noriega, A. E. (2015). Long-run monetary neutrality under stochastic and deterministic trends. Economic Modelling, 47, 372-382.

Westerlund, J., \& Costantini, M. (2009). Panel cointegration and the neutrality of money. Empirical Economics, 36(1), 1-26. 